\title{
A rude ternura do ancião: Maturidade e velhice na poesia de Carlos Drummond de Andrade
}

\section{The rude tenderness of the elder: maturity and old age in the poetry by Carlos Drummond de Andrade}

Marcelo Ferraz de PAULA ${ }^{1}$

Universidade Federal de Goiás (UFG) Faculdades Integradas Promove de Brasília (ICESP)

RESUMO: O presente trabalho desenvolve uma análise das imagens da velhice na poesia de Carlos Drummond de Andrade. Para isso, resgata alguns dos poemas e crônicas reveladores do temperamento característico dos últimos anos de vida do poeta, para, em seguida, fazer um retorno estratégico e ler em sua obra as primeiras manifestações de uma "velhice precoce", revelando sua relação com o "mundo caduco" e com o sujeito gauche.

PALAVRAS-CHAVE: Carlos Drummond de Andrade. Poesia brasileira. Velhice. Tempo.

ABSTRACT: The present paper develops an analysis of images of old age in the Carlos Drummond de Andrade's poetry. For this, it list some of the poems and chronicles that reveal a temperament characteristic of his last years. Then it make a strategic return and reads the firts manifestatations of an "premature old age", revealing their relationships with the "lapsad world" and the gauche.

KEYWORDS: Carlos Drummond de Andrade. Brazilian poetry. Old age.Time.

\section{"Pouco importa venha a velhice; que é a velhice?"}

Carlos Drummond de Andrade

${ }^{1}$ Doutor em Estudos Comparados de Literaturas de Língua Portuguesa pela USP, professor da UFG e das Faculdades Integradas Promove de Brasília. 


\section{0 apelo tardio do poeta}

Diferentemente do que poderíamos a princípio supor, as representações da velhice na poesia de Carlos Drummond de Andrade não oferecem um momento de inauguração capaz de sinalizar uma guinada simbólica que marque a transição do sujeito drummondiano para o outono da existência ou mesmo para o que poderíamos grosso modo definir como uma consciência da maturidade ${ }^{2}$. Em outros termos, se parece válido para a reflexão aqui proposta eleger um poema da acidez um tanto quanto rabugenta (ainda que irônica) de "Apelo aos meus dessemelhantes em favor da paz" como manifesto da velhice - clamor altissonante do recatado idoso entediado com as exigências públicas de sua condição intelectual - o mesmo não parece ser tão confortável ao tentar definir um poema ou livro que marque a entrada de Drummond na madureza, pensada não apenas em termos de plena consciência criativa, mas como etapa natural da vida, com as implicações sociais que lhe são historicamente associadas.

A rigor, o temperamento meio ranzinza e melancólico que marca as representações da velhice nos últimos escritos do autor mineiro já está esboçado desde a primeira página de seu primeiro livro, na imagem predestinada do gauche. As interpretações que a crítica tem elaborado para o gauche passam necessariamente pela noção de recolhimento, pela introspecção, pelo caráter casmurro e ensimesmado profeticamente anunciado

${ }^{2}$ No decorrer desta explanação cuidarei para não fazer o uso indiscriminado
entre "velhice" e "maturidade", palavras de sentidos intercambiáveis mas que
não chegam a constituir sinonímia. Assim sendo, entenderei a velhice como
o estágio mais adiantado da vida, sem a preocupação de definir uma idade
precisa (em favor da análise de seu impacto na subjetividade do poeta e nas
imagens simbólicas que ele utiliza para demarcá-la: cabelo branco, calvície...);
já quando me referir à maturidade, terei em mente um estágio de consolidação
e potencialização da experiência individual, inclusive criativo, mas não
somente. Resgatando a desgastada metáfora na base do seu significado,
pensarei a maturidade, como no caso das frutas, em sua dimensão dialética:
como momento de máximo esplendor e, ao mesmo tempo, início da putrefação. 
por um "anjo torto". Por conta desta vocação ao encerramento em si e ao aspecto taciturno do eu drummondiano, não espanta encontrarmos um verso como o presente em "Verso à boca da noite": "Há muito tempo suspeitei o velho em mim", marcante para pensarmos numa "velhice precoce", que se mostraria tanto na personalidade fundante do gauche como em certa abstinência diante das atividades próprias da infância. Ora, se adentrarmos no poema "Apelo aos meus dessemelhantes em favor da paz" que, num primeiro momento, lerei como emblema da velhice em Drummond, veremos como o apelo tardio do "ancião que mais fala quando cala" funciona como um desdobramento mais ou menos radical do sujeito drummondiano, sempre fechado mesmo quando deseja abertamente a comunicação solidária - e, a certa altura, com orgulho de seu individualismo:

Sou o Velho Cansado

que adora o seu cansaço e não o quer

submisso ao vão comércio da palavra.

Não leio mais, não posso, que este tempo

a mim distribuído

cai do ramo e azuleja o chão varrido,

chão tão limpo de ambição

que minha só leitura é ler o chão.

(ANDRADE, 1996, p. 368)

O tom agressivo do poema é intimamente próximo à forma altissonante dos manifestos. Nele são revelados em clamor raivoso as preocupações que marcavam os últimos anos do poeta de Itabira. Incio propositalmente por este poema porque nele a velhice do sujeito lírico - que no caso é moldado de forma a coincidir com o próprio poeta - ocupa uma posição evidente, declarada e estruturalizante. Uma identidade muito clara é assumida através dos epítetos com os quais a voz lírica se define jocosamente: "Velho Cansado", "macróbio", "ancião". Sua virulência se desdobra nas imagens de apelo, no ânimo amargo, nas súplicas por tranquilidade e pela presença latente da morte, indicada na afirmação de que não chegará a ver as "belezas do 
ano 2000", ou ainda na imagem do tempo escasso que vai caindo do ramo, contida na estrofe já citada. É com esta representação em mente que proponho, mais adiante, um retorno estratégico aos livros centrais de Drummond, seguindo o caminho inverso ao da cronologia da obra, com o intuito de explorar as primeiras imagens de uma velhice precoce e suas implicações nos procedimentos estéticos elaborados nas mais importantes realizações do autor.

Como muitos devem saber, os últimos anos de Drummond foram marcados pelo recolhimento, pela quase total inacessibilidade diante da imprensa e por um almejado distanciamento da vida pública. "Apelo aos meus dessemelhantes [...]" é a defesa veemente, exaltada e agressiva desta fuga das polêmicas mundanas. Dentre elas o poema destaca o desdém às benesses acadêmicas e pedagógicas comumente e cinicamente oferecidas a um laureado "poeta oficial". Outro ponto abordado pelo poema é o das pressões para que o autor proclamasse uma posição mais clara, mais ativista, em relação à conturbada realidade política nacional. Se obviamente ninguém em sã consciência acreditasse que Drummond pudesse retomar o papel combativo que exerceu durante a Segunda Guerra Mundial e no Estado Novo varguista, ao menos desejava-se que com seu prestígio intelectual ele atuasse no projeto de redemocratização do país, que começava a delinear seu futuro após um longo período de terror militar.

$\mathrm{O}$ poeta, entretanto, fatigado e com certas debilidades em sua saúde, clama o direito de sair de cena, ressaltando sua consciente e merecida imersão na segurança do âmbito privado. No poema em questão ele renuncia à imagem pública que supostamente teria de zelar com simpatia (ainda que dissimulada) e voluntarismo (ainda que maçante), não apenas na condição de uma lenda viva da nossa literatura ("tragam-no vivo para uma conferência") mas, como dizia em outros tempos, por ser dentre os nossos poetas "o mais exposto à galhofa"s.

$\mathrm{O}$ poema consegue se manter divertido e áspero ao mesmo

${ }^{3}$ Verso do poema "Canto ao homem do povo Charles Chaplin" (ANDRADE, 1987a, p. 222) 
tempo; é repleto de sacadas auto-irônicas potencializadas pelo distanciamento dramático - estratégia recorrente na obra de Drummond - que o poeta utiliza nos longos trechos em que o sujeito fala de si mesmo na terceiro pessoa:

Vocês, garotos de colégio, não perguntem ao poeta quando nasceu.

Ele não nasceu.

Não vai nascer mais.

Desistiu de nascer quando viu que o esperavam garotos de colégio

É eloquente, sobretudo, no que tange ao desconforto diante dos compromissos oficiais, carregados por uma pomposa artificialidade não mais aceita pelo poeta-ancião cansado, irritado pelo tratamento de celebridade com que era convocado para as mais burocráticas atividades culturais ("Tragam-no vivo para fazer uma conferência", "Cacem o urso polar!"); desgostoso diante da aproximação oportunista de eventuais bajuladores ("Não me tragam originais para ler", "Não exijam prefácios e posfácios") e mesmo diante da sua relevância como expoente literário, da cordialidade algo mesquinha que exigiam da sua posição como “poeta maior", algo que ele nunca levou lá muito a sério:

Tudo esqueceu: responder

cartas; sorrir

cumplicemente; agradecer

dedicatórias; retribuir

boas-festas, ir ao coquetel e à noite

de autógrafos-com-pastorinhas.

Para concluir, exibe, não sem boa dose de ironia, essa condição de indisposição social e de absoluta repulsa ao mundo frio das letras com uma inusitada comparação que, embora se diga resultante do recrudescimento típico da senilidade, tem muito a ver com a tão comentada dificuldade de diálogo e participação que, como aponta Antonio Candido (2004) em célebre ensaio, formam - em constante tensão com o desejo de abertura e comunicação - 
um dos campos de força primordiais da poética drummondiana: "Ficou assim: o cacto de Manuel/ é uma suavidade perto dele". Cacto este que, como bem sabemos, primava pelos três atributos retomados na analogia estabelecida pelo intertexto: "belo, áspero, intratável". Ao se dizer, hiperbolicamente, mais "intratável" do que o cacto de Bandeira, o sujeito se refere à velhice como causa direta das transformações que geraram o cansaço e a consequente necessidade de reclusão social, o que é dado pelas construções verbais no passado, "esqueceu", "ficou assim", dentre outras que assinalam uma mudança mais ou menos recente do ânimo, isto é, "ficou assim" pois antes era de outro jeito. Mesmo assim, insisto na ideia de que mais do que uma mudança repentina causada pelo avanço da idade, tais representações são, acima de tudo, afirmação de um temperamento recatado, presente no melhor da poesia de Drummond, que apenas vêm encontrar seu coroamento nas imagens da velhice, do tédio diante do outono da vida, da decadência senil esboçada nos últimos anos do poeta.

Sem querer alongar-me muito em informações biográficas, vale a pena mencionar a correlação dos motivos presente em "Apelo aos meus dessemelhantes..." com os temas das últimas entrevistas do poeta e várias de suas crônicas desse período ${ }^{4}$. As preocupações denunciadas por Drummond nestes depoimentos estão muito próximas do drama contido no poema examinado até aqui. $\mathrm{Na}$ entrevista concedida à sua filha ou em outra, a Zuenir Ventura, por exemplo, o poeta repete sistematicamente o desgosto em receber homenagens, em se exibir como mito literário ou atender os vários pedidos que lhe chegavam, desde a escrever prefácios até responder perguntas óbvias de estudantes. Nas crônicas estes temas vão se multiplicando, sempre com bom humor e ironia aguçada. Uma delas ("Poeta novo na praça") narra a história de um poeta que faz lastimáveis poemas com palavras retiradas de bula de remédio e insiste para que o "mestre" lhe faça um prefácio. Em outra ("O escritor responde, coitado") enumera as respostas "corretas" para se dar às perguntas feitas

${ }^{4}$ Parte delas reunidas no livro Moça deitada na grama (1987). 
por colegiais; já em "Encontro na calçada" é uma admiradora alucinada que agarra o pobre poeta na saída dos Correios e lhe enche de homenagens indiscretas.

Em outro de seus contos temos outra vez o diálogo entre o velho escritor e um jovem colegial que lhe enche de perguntas filosóficas, as quais o entrevistado logo trata de desconstruir, salientando tanto a condição equívoca do poeta como a limitação do saber dele exigido frente às "grandes questões". Tal esforço visa, evidentemente, desmanchar a imagem alimentada pela tradição já abalada nas grandes sociedades industriais mas ainda presente em nosso imaginário - do idoso (e no caso de Drummond com o "agravante" de ser poeta) como síntese da experiência coletiva, capaz de organizar o conhecimento empírico acumulado durante a vida e expô-lo, sabiamente, para os mais jovens.

Aliás, a problematização desta "essência sábia” do poetaidoso aparece de maneira muito interessante em "A Luis Maurício, infante", poema que dá fecho ao Fazendeiro do Ar (1954). Nele o poeta se dirige ao neto recém-nascido para, nas palavras do poema, "te mostrar o mundo". No entanto, as boas-vindas do avô para o neto vão aos poucos se convertendo num monólogo que expõe tortuosos dilemas filosóficos, que apresenta o encanto da vida e a beleza da linguagem, renegando o didatismo cicerônico em prol do compartilhamento de impressões e de ternura para, enfim, transmitir o valor da dúvida como seu maior legado. O neto recém-nascido vai sendo desenhado como um interlocutor silencioso, mas a situação discursiva apresenta um inusitado equilíbrio entre as duas partes: o neto é tratado como igual pelo avô e emancipado pela seriedade meditativa que a repetição constante e solene do seu nome, Luis Maurício, gera no ritmo do poema.

No caso de Drummond, encontraremos sempre uma dupla revolta contra a exigência de um saber plasmado, pois o sujeito se rebela não somente contra a maturidade - que não traz as respostas semeadas ao longo existência - como pela posição social do poeta em nossa cultura, visto normalmente como portador de verdades 
e de quem se espera sempre palavras inteligentes, ensinamentos, lições espirituosas e uma comiseração serena com a vida e a morte.

Entretanto não podemos esquecer que esse rude canto de revolta contra as convenções e os compromissos entediantes não foi o único expediente adotado pelo poeta para dar vazão aos impasses de seus últimos anos. Em Farewell (1996) e no esforço memorialista de Boitempo (1984) livros que configuram o núcleo das obras poéticas escritas na velhice de Drummond, as distintas estratégias adotadas acabam reafirmando, em maior ou menor grau, a condição de balanço da existência e a reflexão sobre a idade, refundando a memória ou desafiando as convenções sociais construídas em torno da velhice, como ocorre também no erotismo de Amor Natural (1992). Tanto na aproximação mais, digamos, serena da infância (sobretudo se contrastarmos com a forma tensa que Drummond retrata a família nos poemas mais conhecidos) de Boitempo, como no esforço de criar uma poesia fora dos padrões mais celebrados de sua obra (Amor Natural), encontramos o poeta assumindo uma posição e expondo os dramas que embalam sua velhice.

\section{Na curva perigosa dos cinquenta}

Como vimos até aqui, nos últimos anos de Drummond a velhice se apresenta como matéria constante de suas publicações, seja de maneira direta, como nos poemas que analisamos, seja como motivação implícita em seus últimos livros. Dando, porém, um passo para trás no tempo, podemos observar que no chamado núcleo classicizante de sua obra, que abrange Claro Enigma (1951), Fazendeiro do Ar (1954) e A Vida Passada a Limpo (1959) - prenunciada com a pequena série Novos Poemas (1948) - a tematização da maturidade continua ocupando um papel importante na organização emotiva da poética drummondiana.

Não temos nesse período o sujeito autoproclamandose "ancião", "senil" ou suas variantes. O poeta, nessa fase, se 
mantém ainda a certa distância da debilidade física que afetaria drasticamente o seu ânimo nas décadas seguintes. Não há ainda o cansaço físico e mental atribuídos à senilidade, mas temos o anúncio, o pressentimento da vivência outonal e da certeza de incompletude que acompanha as representações da velhice em Drummond. Em estudo detido de Claro Enigma, Vagner Camilo chega a citar no seu Da Rosa do Povo à Rosa das Trevas (2001) a etapa da maturidade - aqui vista como a porta de entrada para a velhice - como um dos condicionantes para o pessimismo dominante na obra de 51. No entanto, sua argumentação prioriza a decepção de Drummond com o proselitismo e o fanatismo partidário, interpretados no seu estudo como motivação para a guinada classicizante e para o desencanto frente ao discurso politicamente comprometido, deixando a questão do envelhecimento num segundo plano, como "justificativa natural para as motivações históricas da melancolia dominante no livro" (CAMILO, 2001, p. 175).

Sem o intuito de diminuir a importância da frustração política do poeta mineiro diante do dogmatismo do PCB, podemos argumentar que a iminência da velhice, isto é, o suposto fim da vitalidade questionadora própria dos jovens e a ameaçadora chegada da "idade crepuscular" - que pode ser lida em conexão com as abundantes imagens da noite presentes no livro - constituem um papel destacado na reflexão amarga e cética que dá o tom de Claro Enigma e dos livros que o sucedem. Advogar uma presença mais contundente do "manto da velhice" no pessimismo de Drummond é, além de tudo, preencher uma lacuna necessária inclusive para a melhor compreensão dos últimos livros do autor, escritos já "para lá dos setenta anos" para lembrarmos a fantasmagórica presença do pai morto em "Viagem na Família" - sendo a maturidade estética e expressiva de Claro Enigma o período de reflexão, de balanço da trajetória do poeta e do homem.

Em outras palavras, seria el mezzo del camino, momento em que com as "mãos pensas", "entre lobo e cão", o poeta "avalia 
o que perdera", sendo o livro a encenação dessa passagem de uma empolgação, tão convicta quanto problemática (sobretudo no que tange ao entusiasmo político), para a reticente velhice outonal. Sem o intuito de me aprofundar em tão complexo poema, cito "A máquina do mundo" como dramatização de um sujeito que se insere numa trajetória de vida na qual o espectro da maturidade fica latente a todo instante.

Já distante da euforia da mocidade e, por isso mesmo, cansado de percorrer, "vagamente", a simbólica "estrada de minas pedregosa", o poeta encontra a máquina do mundo em um fatídico momento de decadência e desgaste, ligados à peculiaridade de um momento da vida, que influenciarão a famosa renúncia - "para quem de a romper já se esquivava" ou "a quem de os ter usado os já perdera". Dessa maneira, uma das causas para a recusa, como já apontaram vários de seus intérpretes, surge devido a sua anunciação num momento em que a mínima esperança já estava ausente; porque a máquina é oferecida não ao jovem, ávido por sentidos, que tanto a buscara, mas sim a "um novo ser, não mais aquele/ habitante de mim há tantos anos", este ser já distante da euforia da descoberta, da empolgação frente à novidade, ou seja, já desconfiado da demora das promessas da mocidade, a tal ponto de abrir mão da dádiva que lhe foi, gratuitamente, exposta fora do tempo em que poderia ser colhida.

Há nos livros classicizantes de Drummond um recorrente movimento de "avaliação" do passado, que interpreto aqui, apoiado na leitura do já mencionado livro de Vagner Camilo, como um acerto de contas com as convicções anteriores. Somente com o devido julgamento da entrega solidária buscada sobretudo em A Rosa do Povo (1945), é que o sujeito poderia entrar no estágio de plena maturidade. Enquadro nessa categoria poemas de teor avaliativo que se expressam, por exemplo, através de análises do poeta sobre suas obras anteriores, como em "Legado" e "No exemplar de um livro velho", que hipotetizam possibilidades, juízos, julgamentos simbólicos do eu diante de sua "vida passada a limpo", bem como suas conquistas, remorsos, 
quimeras e hipotéticas omissões, como por exemplo em "Ser" ("O filho que não fiz/ hoje seria homem"), "A ingaia ciência", e, de uma maneira mais problemática, na tematização da memória nos poemas familiares - penso especialmente no sentimento de culpa presente em "A mesa", com o sujeito justificando para o pai os caminhos que escolheu: poesia, ida para cidade grande, tomada de consciência - que o separaram do legado patriarcal da família mineira.

Não por acaso, as motivações históricas e o estágio de vivência do poeta convergem para a mesma imagem crepuscular no capítulo que abre o livro ("Entre lobo e cão"), do qual o primeiro poema é "Dissolução":

Escurece e não me seduz tatear sequer uma lâmpada.

Pois que aprouve ao dia findar aceito a noite.

(ANDRADE, 1987a, p. 245)

As imbricações entre maturidade e decepção política parecem de tal maneira unidas que torna-se difícil pensar o entusiasmo da militância poética - vivenciado não sem a devida precaução pelo poeta - com a luz perdida na passagem para a maturidade. Preâmbulo da velhice, a maturidade surge como descoberta de uma realidade mais problemática do que o desejo de abertura poderia superar. Ciente de não haver outras opções, o sujeito aceita a noite com um misto de tragédia e conformismo: "Pois que aprouve ao dia findar/ aceito a noite". Daí a entrada na noite corresponder, simultaneamente, à entrada num momento de descrença política e na própria madureza, que como dissemos "é a justificativa natural para o desengano - valendo lembrar que, para a antiga teoria dos humores, essa seria a fase da vida que melhor corresponde ao temperamento melancólico" (CAMILO, 2001, p. 175).

No poema "Legado" o que mais nos interessa é a retomada crítica do emblemático verso modernista "No meio do caminho 
tinha uma pedra" (ANDRADE, 1930) como chave de ouro em um soneto rigidamente elaborado, com precisão e regularidade milimétrica. Não nos importa tanto se a construção, de aspecto (neo)parnasiano, é irônica, como defende Achcar, ou se atende ao "tédio alienante" da arte pela arte, como acusa Haroldo de Campos. O que vale destacar é a sua estrutura reflexiva: o poema apresenta duas camadas temporais, uma delas imediata, a da maturidade, visível nas considerações que o sujeito tece sobre a ilusória perenidade da sua poesia, e outra implícita, que se refere ao poeta em seu primeiro livro, ainda jovem e exposto à estrondosa polêmica do verso em questão. A readequação do debochado verso modernista à poética castiça do soneto aponta para uma vitória dessa maturidade vivida em Claro Enigma sobre a inconsequência do livro de 30 - independente dessa vitória ser irônica ou não.

É diferente, portanto, da estrutura de "No exemplar de um livro velho" (poema d'O Fazendeiro do Ar), onde apesar de termos uma situação semelhante - o poeta ponderando sobre uma de suas obras anteriores - a ironia certamente se dá de maneira inversa. Nele devemos atentar para a aparente nostalgia que o poema deixa transparecer na última estrofe:

e um grave sentimento que hoje, varão maduro, não punge, e me atormento.

(ANDRADE, 1987, p. 305)

A noção de que a maturidade acarreta a perda de um sentimento audacioso e espontâneo, tipicamente juvenil - "desejo obscuro de modelar o vento", "susto secreto" - é contrastada pela forma escolhida pelo poeta para dar vida a esta matéria. A ordenação sóbria da forma poética, os tercetos uniformes, rimados e de uma quietude justa e precisa, ao mesmo tempo negam e endossam a sensação de perda presente nos seus versos finais. O complexo drama encenado no poema é o de que há uma compensação, provavelmente não equilibrada, entre o que a idade madura perde de audácia e espontaneidade e a conquista de um 
domínio maior sobre a linguagem poética, vista na estruturação amena e ordenada do poema que homenageia Brejo das Almas (1934).

Outro soneto de Claro Enigma a tratar da maturidade é "A Ingaia Ciência". Nele a madureza surge como uma "terrível prenda", expondo a fugacidade do tempo e a marcha da idade:

A madureza, esta terrível prenda, que alguém nos dá, raptando-nos, com ela, todo sabor gratuito da oferenda sob a glacialidade de uma estela.

(ANDRADE, 1987a, p. 246)

Além da noção de decadência, o poema exibe uma amarga descrença nos benefícios eventuais deste amadurecimento, visto que as possíveis experiências que ela traz ou são desprezíveis ou não resolvem os problemas próprios do envelhecer:

A madureza sabe o preço exato dos amores, dos ócios, dos quebrantos, e nada pode contra sua ciência e nem contra si mesma [...]

(ANDRADE, 1987a, p. 246)

Desta maneira, vale salientar no poema como "não há compensação alguma [...], os ganhos alcançados com a maturidade não servem absolutamente de reparo ao que se perdeu com ela." (CAMILO, 2001, p. 179). A visão da velhice surge com uma negatividade capaz de esvaziar qualquer possibilidade de conquista, cabendo apenas a conformação - não pacífica e muito menos ingênua -, como vimos na aceitação do crepúsculo em "Dissolução".

Outra importante manifestação da velhice na etapa classicizante, ou filosófica, como prefere Carpeaux, da poesia de Drummond é a temática do "amor crepuscular"; o amor nos tempos de madureza, que surge num momento de decadência, "quando os frutos ou não são colhidos ou sabem a verme". Os poemas emblemáticos para a questão são "Campo de flores" e 
"O quarto em desordem", ambos destacando logo nos primeiros versos a condição madura do sujeito amante.

No caso do soneto "O quarto em desordem", de Fazendeiro do $A r$, a primeira estrofe é quase proverbial:

$\mathrm{Na}$ curva perigosa dos cinquenta derrapei neste amor. Que dor! que pétala sensível e secreta me atormenta e me provoca a síntese da flor.

(ANDRADE, 1987a, p. 307)

A imagem dos dois primeiros versos explora a idade fatídica dos cinquenta anos como uma curva na estrada do envelhecimento, na qual a vivência do amor só poderia ser uma "derrapagem". Trata-se, portanto, de um amor que tem o poder de desviar o eu-lírico (condensado na metáfora de um automóvel ou de algo em movimento) da rota inevitável da velhice. No entanto, por surgir na "idade madura" a paixão é ambígua (mais à frente essa ambiguidade é exposta no próprio poema pelo verso "a nuvem que de ambígua se dilui"); conforme sugere a imagem da estrada, o brusco desvio causado por um amor no momento em que ele não soa mais como natural, ao mesmo tempo que retira o sujeito da melancolia e da decrepitude, presenteando-o com uma espécie de juventude tardia, também parece lhe desviar de um trajeto do corpo (mas não somente dele) que é natural, espontâneo, inevitável. A consumação amorosa na velhice ressoa a sua incompletude inerente - vide a "desordem" do quarto, contida no título, resultante da liberação do desejo e índice da própria condição na qual o amor se emancipa. O mesmo vale para o apelo à "sede tão vária" e na insistência com que o poema alude ao corpo, como também parece mostrar a metonímia da pétala que, "sensível e secreta", substitui a própria flor, e toda a dimensão erótica que ela carrega.

Assim, o desejo saciado encontra sua complementação na surpresa de um amor deslocado, pejorativamente fora de época, que surge em uma "curva perigosa" e sobre o qual o poeta "derrapa", como num deslize, um lapso, sem as devidas 
precauções; é nessa contradição entre desejo e madureza que o poema vai tecendo seus sentidos.

A partir disso, passo a examinar com mais proveito o erotismo latente dos versos finais:

verdade tão final, sede tão vária, e esse cavalo solto pela cama

a passear o peito de quem ama.

Neste último terceto a ênfase recai sobre a virilidade, materializadas na "sede tão vária" e na metáfora do cavalo passeando pelo peito amante. É como se o pudor do amor maduro fosse estilhaçado pelo prazer da consumação sexual, restando, após o gozo, a imagem de desconforto e liberdade do quarto em desordem. A função que o erotismo cumpre neste poema é o gancho para interpretarmos as profundas relações que a lírica amorosa de Drummond estabelece, a partir de Claro Enigma, com a velhice.

No livro de 1951, sobretudo em "Campo de Flores", e nos livros que o sucedem, como vimos em "O quarto em desordem", Drummond tende a tematizar a paixão correspondida e quase sempre consumada. É na madureza que o desespero resultante da ilusão do amor frustrado perde espaço em sua poesia, assim como o tom irônico em que o poeta talhava a aventura da paixão nos primeiros livros, como podemos ver nos desencontros sucessivos de "Quadrilha" (Alguma poesia) ou a representação sarcástica de um romantismo suicida e estéril, como em "Não se mate" ou "Necrológios dos desiludidos do amor", ambos de Brejo das Almas (1934).

É sabido que Brejo das Almas é o livro em que a poesia amorosa é mais abundante na trajetória de Drummond, fato interessante por se tratar, nas palavras de John Gledson (1981), de uma obra que se mostra "produto de uma crise", "retrato de um mundo irreparavelmente falso". No caso do livro de 1934, a paixão febril e a preocupação melodramática com o suicídio convergem para um estado de espírito inquieto, cético, sendo 
o amor mais um ideal platônico, esvaziado e patético, do que a consumação erótica do sentimento amoroso.

No longo caminho que separa Brejo das Almas de Claro Enigma a paixão febril da juventude vai cedendo lugar à sobriedade da paixão madura, ou paixão crepuscular, para utilizarmos o termo presente em "Campo de Flores". Certamente a insistência no erotismo que observamos a partir de Claro Enigma - e que vai atingir seu ápice em Amor Natural, livro póstumo, escrito já na casa dos 80 anos - possui uma crítica bastante sutil e contundente. Em Amor Natural, como explica Vivaldo Andrade dos Santos (2002), no livro Trem do Corpo, o poeta hesitava em publicar a obra, na qual "o erótico é levado à máxima potencialidade", como liberação do autor à esterilidade senil, mas a tal ponto que ele teme uma recepção equivocada dos poemas como obras pornográficas, vulgares. Desse modo, na medida em que o sujeito amante assume a condição de maturidade e, mais tarde, de idoso, a poesia de Drummond questiona sutilmente uma convenção social ainda difundida em nossa cultura: a da castidade na velhice.

É a chegada de um amor que surge quando nada mais se espera da vida, e quando o próprio amor já parece não ser possível, talvez até patético; isto é, mostra-se imoral conforme o avanço da idade. Esse é o pano de fundo da tensão que expressa as dúvidas do sujeito diante da paixão - enfim correspondida - mas aparentemente anacrônica, que chega tarde, tal como a revelação que sugeri na breve interpretação de "A máquina do mundo". E este o dilema vivenciado na primeira estrofe de "Campo de flores":

Deus me deu um amor de madureza, quando os frutos ou não são colhidos ou sabem a verme. Deus - ou foi talvez o Diabo - deu-me este amor maduro, e a um e outro agradeço, pois que tenho um amor.

(ANDRADE, 1987a, p. 267)

Trata-se de um amor que oscila entre a predestinação - "Deus me deu" - e a dúvida quanto a sua validade devido à condição de madureza, repetida duas vezes só nesta primeira 
estrofe, que em princípio assume uma carga negativa graças à imagem de putrefação contida no segundo verso. Há um embate constante entre a aceitação deste amor como dádiva tardia e o mal-estar gerado pela própria condição de maturidade, a ponto de gerar um relacionamento amoroso que não seria propriamente sagrado, pois pode ser inclusive um presente demoníaco. $\mathrm{O}$ amor é mais adiante chamado de "crepuscular" e exige cuidados diferentes, "uma grave paciência", sendo uma recompensa tardia às cicatrizes de amores anteriores. Ainda que sem o apelo erótico evidente em "O quarto em desordem", "Campo de flores" é o primeiro dos poemas de Drummond a apresentar o convite amoroso numa idade hostil, "onde os frutos não são colhidos".

Não por acaso, o poema em questão, e mais adiante todo o Amor Natural, foram recebidos com pudor por parte do público, como se tratasse de uma perversão senil de Drummond, já que problematizam uma longa tradição que torna tabu o sexo a partir de determinada idade. Desta tradição, cujas manifestações fundamentais foram o carpe diem horaciano e o amor romântico, ambos estabelecendo uma conexão estrita entre amor e juventude, Drummond ecoa a dúvida diante de um sentimento que se revela fora do tempo demarcado para a experiência carnal, e, a partir das dúvidas, engendra a superação de tais padrões através da imagem que fecha "Campo de flores", quando a presença do amor arrasta o sujeito para fora do tempo crepuscular: "e estou vivo na luz que baixa e me confunde".

\section{0 pressentimento à boca da noite}

Não há dúvidas de que na cultura ocidental pensar a velhice leva quase automaticamente à consciência da finitude humana, aos refluxos da memória e à fugacidade da existência. Há uma conexão tão íntima entre tais questões que privilegiar o tema da velhice requer um exercício muitas vezes questionável, mas certamente necessário, de filtragem destes outros motivos que lhe acompanham. É o caso exemplar dos poemas familiares de 
Drummond, especialmente os que encenam um diálogo do sujeito com o pai morto. Neles a velhice aparece em camadas secundárias, refletidas na imagem do pai, através de símbolos ternamente escolhidos: as rugas ("Não mais te peço a mão enrugada", em "Como um presente"), ou mais claramente na contagem dos anos do pai após a sua morte, como em "Viagem na Família" ("Seu rosto longe/ para lá de setenta anos"s) ou "Ai, velho, ouvirias coisas/ de arrepiar os teus noventa" - "A mesa"). Pela própria natureza deste trabalho, deixarei de considerar as manifestações da velhice na lírica familiar de Drummond, evitando o risco de considerar sem o devido cuidado as relações que, nestes casos principalmente, a velhice (do pai e dos parentes) estabelecem com a morte, o patriarcado e com os laços familiares. Sem desprezar o interesse de tal ponderação para um trabalho de maior fôlego, me concentrarei aqui somente nos poemas em que o sujeito encara o seu próprio envelhecimento.

Tendo isso em mente, conduzo nossa reflexão para passagens da dita poesia social de Drummond. Em A Rosa do Povo, livro símbolo desta postura de comprometimento do poeta com os problemas de seu tempo, encontramos o que poderia ser nomeado como um ensaio da consciência de maturidade que iria marcar os livros seguintes. Se em Claro Enigma o sujeito se vê imerso na "terrível prenda" da maturidade que, como defende Vagner Camilo, surge como justificativa natural para a imersão do poeta na noite, no livro de 45 a madureza é ainda (ou já) vista como ameaça próxima, iminência, pressentimento, como podemos comprovar nos versos de "América":

Passo a mão na cabeça que vai embranquecer.

$\mathrm{O}$ rosto denuncia certa experiência.

A mão escreveu tanto, e não sabe contar!

(ANDRADE, 1987a, p. 195)

Os versos anunciam a entrada do sujeito pelas veredas da velhice. O recurso utilizado para simbolizar a passagem do

${ }^{5}$ Setenta anos é a idade precisa em que o pai do poeta veio a falecer. 
tempo é o mesmo daquele adotado nos diálogos com o pai: o embranquecimento da cabeça adotado como índice visível dos impactos do tempo. Também fica patente certa desconfiança diante dos resultados trazidos pela maturidade: a experiência acumulada e o muito que se escreveu não são suficientes para garantir a comunicação com os outros, ou mesmo para expor, através da linguagem, a totalidade da realidade apreendida. Alcides Villaça (2006) é um dos estudiosos que destacam essa constante inquietude, que, segundo ele, deixa escapar, mesmo nos poemas de máxima elaboração, um sutil desconforto diante da expressão. Trata-se do mesmo desgosto presente nos famosos versos de "A flor e a náusea" - "Quarenta anos e nenhum problema/ resolvido, sequer colocado" - no qual a experiência acumulada não parece capaz de se converter em conhecimento para a ação/expressão, tornando a vida alienada a partir de um envelhecer que se consuma sem enfrentamento ativo dos dilemas individuais e coletivos.

Tanto em "América" como em "A flor e a náusea" já aparece esboçada a negação veemente que Drummond faria, anos mais tarde, da imagem do poeta senil como portador de uma sabedoria elevada. A diferença entre a rispidez agressiva que apontamos nos últimos anos de vida do autor - seja em "Apelo aos meus dessemelhantes[...]" ou nas crônicas mencionadas - e as tematizações da maturidade dispersas em A Rosa do Povo se limita ao compromisso social firmado em cada uma delas: em "América", por exemplo, a comunicação é conturbada, talvez até impossível, mas sem dúvidas desejada pela relação solidária que o sujeito almeja estabelecer com o meio e as pessoas, representados no poema pela abstração humanizadora do continente americano; ao passo que em "Apelo aos meus dessemelhantes..." a comunicação permanece impossível, mas não é mais desejada, pelo contrário, há uma repulsa veemente à vida social, uma obsessão do sujeito pelo reduto privado.

O pressentimento da velhice, simbolizado no verso "Passo a mão na cabeça que vai embranquecer", reaparece em outros 
poemas do livro de 1945. Em "Versos à boca da noite" ela é dada através de expediente semelhante ao utilizado em "América", com a descrição de elementos do corpo que começam a se transformar, ou melhor, começam a ser transformados pelo tempo:

Sinto que o tempo sobre mim abate sua mão pesada. Rugas, dentes, calvas...

Uma aceitação maior de tudo, e o medo de novas descobertas.

(ANDRADE, 1987a, p. 192-193)

Os efeitos da velhice são dados a partir de dois planos, um deles físico ("rugas, dentes, calvas") e outro psicológico, "uma aceitação maior de tudo", que resulta numa hesitação maior diante das mudanças que ganha forma na segunda estrofe:

Escreverei sonetos de madureza?

Darei aos outros a ilusão de calma?

Drummond chega a antecipar as mudanças de sua poesia, sendo os "sonetos de madureza" assumidos - não sem as problematizações que o teor provocador da pergunta já torna inevitáveis - na lírica classicizante de Claro Enigma. E na estrofe seguinte relaciona a velhice não apenas a um estágio da vida, mas a um estado de espírito - entre o rabugento e o gauche, como vimos - que define sua condição:

Há muito tempo suspeitei o velho em mim.

Ainda criança já me atormentava.

Hoje estou só. Nenhum menino salta

de minha vida para restaurá-la.

O velho acompanhava, desde cedo, a formação emotiva do sujeito, mas agora, às vésperas da madureza, a criança já não existe, "nenhum menino salta de minha vida para restaurá-la"; o que mostra, na trajetória deste sujeito outonal, uma predominância dos atributos próprios da velhice em oposição à jovialidade, à espontaneidade alegre típica da infância, buscada apenas na memória, entre o remorso e as sabidas distorções da lembrança. 
Importante frisar como o poema se constrói não como fruto dessa maturidade evocada nos versos, mas sim como iminência. A começar pelo título, "Versos à boca da noite", capaz de se mostrar próximo, à beira da velhice, sem no entanto julgar-se dentro dela. Vale também destacar a metáfora que representa a velhice com a fatídica imagem da noite, antecipando de certa forma os versos de "Dissolução".

Por fim, temos em "Idade madura", poema que antecede "Versos à boca da noite" na coletânea de 1945, mais uma vez a consciência da maturidade como marca que diferencia A Rosa do Povo dos livros que o antecedem. Diferentemente dos poemas que acabamos de analisar, "Idade Madura" não enfatiza a chegada da maturidade como decorrência latente, mas surge com um caráter positivo (com todas as imbricações e questionamentos que iluminam os momentos de abertura do sujeito drummondiano) no qual a madureza adquire um raro poder de contentamento:

As lições da infância

desaprendidas na idade madura.

Já não quero palavras

nem delas careço.[...]

Nem mesmo sinto falta

do que me completa e é quase sempre melancólico.

(ANDRADE, 1987, 190)

Nos dois primeiros versos a sintaxe incompleta, beirando o anacoluto, converge para a anulação das ditas "lições da infância" como base para a liberdade do poeta maduro, como fica claro mais adiante: "Estou solto no largo mundo"; "Já não dirão que estou resignado/ e perdi os melhores dias". Apesar desse forte movimento de abertura, a idade ainda não se constitui como resolução pacífica das contradições do sujeito - o que de fato seria uma contradição com os outros poemas que acompanhamos até aqui:

descobri na pele certos sinais que aos vinte anos não via.

Eles dizem o caminho, 
embora também se acovardem

em face a tanta claridade roubada ao tempo.

(ANDRADE, 1987a p. 191)

\section{Considerações finais}

A partir da análise dos poemas de Drummond que mencionam a chegada da velhice ou a noção de maturidade, de A Rosa do Povo, momento em que ela aparece deliberadamente pela primeira vez, até seus últimos trabalhos, já próximos da morte do poeta, em 1987, temos uma linha geral das preocupações existenciais que atuam decisivamente nas escolhas poéticas do autor e na constituição de seus livros.

Na medida em que o poeta assume para si uma posição discursiva de maturidade (concretizada no poema por palavras deste campo lexical, como ancião, avô, velhice...), intensificase o tratamento de temas que lhes são complementares, como a presença da morte, a passagem ininterrupta do tempo e os resquícios da memória. Assim, as primeiras imagens da velhice se anunciam vagamente nos cabelos que embranquecem, nas primeiras rugas, que problematizam a chegada do amor maduro e culminam numa vigorosa necessidade de reclusão e descanso, ainda assim capaz de deliciosa ironia.

Em termos gerais, Drummond deixa transparecer em seus poemas a recusa a dois padrões de velhice: o da inutilidade senil (inclusive sexual), resultante do pathos pelo novo (ARENDT, 2007) e o da desbotada, mas ainda existente, imagem da tradição. que celebra os mais vividos como porta-vozes da experiência coletiva e sábios detentores do conhecimento. Com os impasses que marcam a produção do poeta mineiro, temos uma dupla recusa capaz de romper clichês e dramatizar o conturbado trânsito para o outono da vida, sem a aceitação que, na sua lógica, consistiria na omissão da pesquisa do viver, mas também sem a revolta estéril diante do inevitável. Numa posição crítica, entre o sentimento de decadência e a celebração da dignidade humana, em qualquer 
idade, Drummond envelhece, deixando em seus poemas um importante legado para que nós, leitores, conquistemos, sem medo - e sobretudo sem vergonha de ter medo - a maturidade e suas prendas irrevogáveis.

\section{REFERÊNCIAS}

ANDRADE, Carlos Drummond de. Nova Reunião. Rio de Janeiro: José Olympio, 1987a.

. Moça deitada na grama. Rio de Janeiro: Record, 1987b. . Antologia Poética. São Paulo: Record, 1996.

ARENDT, Hannah. Entre o passado e o futuro. São Paulo: Perspectiva, 2007.

CAMILO, Vagner. Da rosa do povo à rosa das trevas. São Paulo: Ateliê Editorial, 2001.

CANDIDO, Antonio. Inquietudes na poesia de Drummond. In: . Vários Escritos. São Paulo: Óleo sobre azul, 2004.

GLEDSON, J. Poesia e poética em Carlos Drummond de Andrade. São Paulo: Duas Cidades, 1981.

SANTOS, V. A. O trem do Corpo. São Paulo: Nankim, 2002.

VILlAÇA, Alcides. Passos de Drummond. São Paulo: Cosac Naify, 2006.

Recebido em 21/03/2013.

Aprovado em 17/10/2013. 